\title{
THREE NEW SMALL-FLOWERED CYRTOCHILUM SPECIES (ORCHIDACEAE: ONCIDIINAE) FROM COLOMBIA AND PERU, AND ONE NEW COMBINATION
}

\author{
Stig DALSTRÖM ${ }^{1,3} \&$ SAUl Ruíz PÉREZ ${ }^{2}$ \\ ${ }^{1} 2304$ Ringling Boulevard, unit 119, Sarasota FL 34237, U.S.A. \\ Lankester Botanical Garden, University of Costa Rica, Cartago, Costa Rica \\ and National Biodiversity Centre, Serbithang, Bhutan \\ ${ }^{2}$ Allamanda 142, Surco, Lima 33, Peru \\ ${ }^{3}$ Corresponding author: stigdalstrom@juno.com
}

\begin{abstract}
Three new small-flowered Cyrtochilum species from Colombia and Peru are here described, illustrated and compared with similar species, and with one new taxonomic combination. The first species differs from all other Cyrtochilum species by the curved horn-like structures on the lip callus. The second species differs from its most similar relative by a larger flower with a different column structure. The third species is distinguished by the three horn-like knobs at the apex of the column.
\end{abstract}

Key words: Cyrtochilum, Orchidaceae, Oncidiinae, new combination, new species, Colombia, Peru, taxonomy

The Andean orchid genus Cyrtochilum Kunth, is rapidly growing in number of species as previously unexplored areas are targeted for botanical inventories, sometimes into areas that have been, or still are, considered "dangerous" by governments for various reasons. In other cases, new species are found in herbaria where they have been laying undetermined in peaceful anonymity for years. This article presents two new species from the Cusco and Ayacucho regions in Peru, which has been terrorized by the Maoist guerilla known as "Sendero Luminoso" (Shining Path) for many years. Today smaller factions of this violent group apparently still control remote bases in the mountains between the city of Ayacucho and the Apurimac river to the east. What is left of the terrorist-like organization is suspected to work as mercenaries for the illegal cocaine drug industry, also established in the region. In other words, this particular area is best given a wide berth! The third species described in this article is also from an area that until very recently was considered very dangerous to visit due to the activities of the FARC guerilla in Colombia. Great work has been done by the Colombian government, however, to clear most of the country from the dangers caused by this group.

Cyrtochilum corniculatum Dalström, sp. nov.

TYPE: Colombia. Antioquia, Yarumal, Km 87 along road Medellín-Yarumal, Llanos de Cuiba [Cuiva], 2750 m, 12 Sep. 1984, C. Dodson et al. 15264 (holotype, RPSC; isotype, MO). FIg. 1.

Diagnosis: Cyrtochilum corniculatum differs from all other small-flowered Cyrtochilum species by the combination of a column with two large ventral, lamellate angles, and a cordate, cupulate lip with a callus of two basal, falcate corniculate denticles.

Epiphytic herb. Pseudobulbs apparently caespitose, subtended basally by 8 to 10 distichous sheaths, the uppermost foliaceous, ovoid, unifoliate or bifoliate, $8.0-9.0 \times 2.5-3.0 \mathrm{~cm}$. Leaves subpetiolate, conduplicate, obovate, acuminate, ca. 36.0-40.0 $\times$ $2.8-3.0 \mathrm{~cm}$. Inflorescences multiple, axillary from the bases of the uppermost sheaths, wiry to $c a .1 .5 \mathrm{~m}$ or longer panicles, with widely spaced, fractiflex or flexuous, 3 to 8 -flowered side-branches. Floral bracts appressed, scale-like, 5.0-20.0 mm long. Pedicel with ovary $7.0-15.0 \mathrm{~mm}$ long. Flower stellate; dorsal sepal pinkish brown, shortly unguiculate to cuneate, elliptic to obovate laminate, obtuse to acute, $10.0-15.0$ $\times 6.0-7.0 \mathrm{~mm}$; lateral sepals similar in color, shortly unguiculate to narrowly cuneate, obovate laminate, acute, $12.0-13.0 \times 5.0-6.0 \mathrm{~mm}$; petals similar in color, unguiculate, slightly obliquely ovate laminate, obtuse to acute, $10.0-12.0 \times 5.0 \mathrm{~mm}$; lip similar in color, 


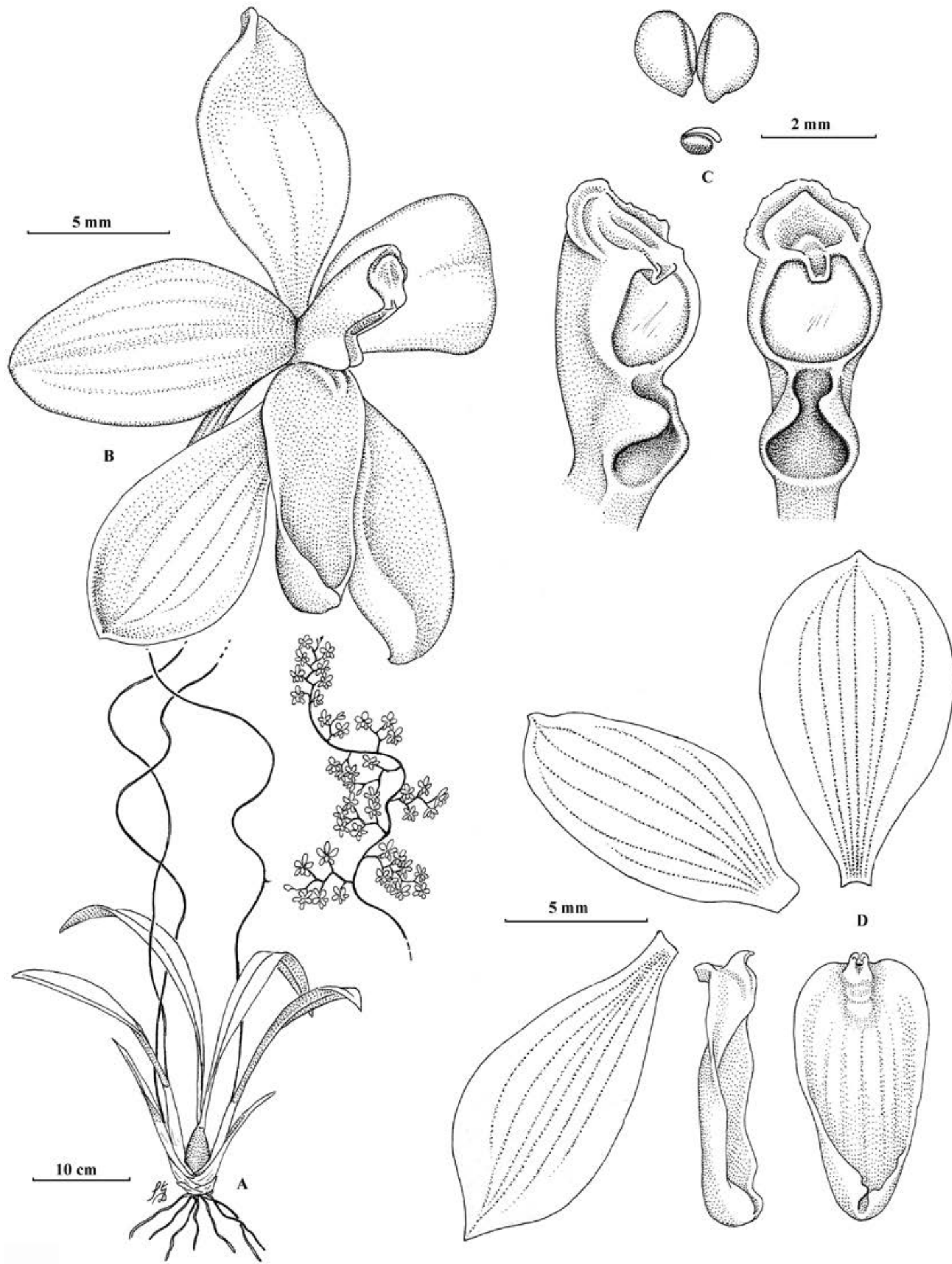

FIgURE 1. Cyrtochilum corniculatum. A. Plant habit. B. Flower lateral view. C. Column, lateral and ventral views, and pollinarium. D. Flower dissected. Drawn from holotype by Stig Dalström. 
rigidly fused to the base of the column and angled downwards in a $c a .135^{\circ}$ angle, cordate to weakly trilobate, with spreading, rounded side lobes, and a cupulate involute, emarginate front lobe, $c a .10 .0 \times 5.0$ $\mathrm{mm}$; callus yellow, of a low basal swelling with a pair of forward projecting, falcate corniculate denticles; column stout, erect, with a pair of ventral, forward projecting, laterally flattened and slightly incurved angles, and a truncate apex, $c a .5 .0 \mathrm{~mm}$ long; anther cap not seen; pollinarium of two globose, cleft, or folded, pollinia on a minute $c a$. $0.7 \mathrm{~mm}$ long stipe, on a $0.5 \mathrm{~mm}$ long, pulvinate viscidium.

Paratype: Colombia. Cundinamarca (?), "Bogota", "Falkenberg" s.n.; the quoted information is marked with question marks on the herbarium sheet (W 15932).

Distribution: Recorded from the Llanos de Cuiva area in the central cordillera of the Colombian Andes, at an elevation of $2750 \mathrm{~m}$, and once (questionable) from the eastern cordillera, possibly somewhere near Bogota.

Eтymology: Named in reference to the falcate, hornlike denticles of the lip callus.

Cyrtochilum corniculatum is only known from two collections, which is remarkable since it comes from rather heavily collected regions. The habitat is epiphytic in patches of upper elevation cloud forest, in rather deforested areas. The insignificant pinkish brown flowers on long and wiry inflorescences may have contributed to the plant not being observed or appreciated by previous collectors.

Cyrtochilum russellianum Dalström \& Ruíz-Pérez, sp. nov.

TYPE: Peru. Ayacucho, La Mar, Aina, Calicanto, humid cloudforest at $2500-2600 \mathrm{~m}$, collected by $\mathrm{S}$. Ruíz, J. Valer and S. Dalström of Peruflora, 5 Dec. 2010, S. Dalström 3415 (holotype, USM). FIG. 2.

Diagnosis: Cyrtochilum russellianum is most similar to the sympatric Cyrtochilum carinatum (Königer \& Deburghgr.) Dalström, comb. nov. (Basionym: Trigonochilum carinatum Königer \& Deburghgr., Arcula 19: 430. 2010), but differs primarily in having a larger flower without the well-developed dorsal column ridge, which ends in a distinct apical knob, typical for C. carinatum. It differs from the also sympatric $C$. sharoniae Dalström, by the light rose flowers versus dark blackish purple flowers of the latter species.

Epiphytic herb. Pseudobulbs caespitose, ovoid, unifoliate or bifoliate, surrounded basally by distichous, foliaceous sheaths. Leaves subpetiolate, conduplicate (no vegetative parts exist in the type specimen. The relatively large type plant was examined but unfortunately not measured). Inflorescence axillary from the uppermost sheaths, erect, then more or less wiry, to $c a$. 1.8-2.0 m long panicle with widely spaced 4- to 6-flowered flexuous side-branches. Floral bracts appressed, scale-like $c a .3 .0-5.0 \mathrm{~mm}$ long. Pedicel with ovary triangular in cross-section and slightly winged, ca. $25 \mathrm{~mm}$ long. Flower stellate with more or less deflexed segments; dorsal sepal white almost covered by pale rose blotches, spathulate, elliptic laminate, acute, slightly undulate, $12.0 \times 5.0 \mathrm{~mm}$; lateral sepals similar in color, spathulate, ovate laminate, obtuse, slightly oblique $c a .12 .0 \times 4.0 \mathrm{~mm}$; petals similar in color, shortly spathulate, obliquely obovate to rotund laminate, acuminate, $10.0 \times 6.0 \mathrm{~mm}$; lip whitish to pale yellowish with pale brown to purple spots, rigidly attached to the base of the column, hastate, triangular with distinctly angled side lobes and an obtuse slightly revolute, recurved and apically convolute front lobe, ca. $10.0 \times 7.0 \mathrm{~mm}$; callus pale yellowish with brown spots, of a fleshy, multidentate structure, extending from the base to about half the length of the lamina, with spreading, rounded knobs, and ending in a central, slightly larger rounded denticle, with two lateral, spreading, short, knoblike denticles; column lilac, erect, almost straight to slightly sigmoid, with a basal, ventral knoblike swelling, and then with two spreading ventral angles below the stigmatic surface, $c a$. 4.5-5.0 $\mathrm{mm}$ long; anther cap red, globular; pollinarium of two elongate pyriform, cleft, or folded pollinia on a minute linear stipe, on a micro-minute pulvinate viscidium.

Distribution: Cyrtochilum russellianum is only known from a single locality; the upper elevation cloudforests near the village of Calicanto, east of Ayacucho, Peru, in the centre of the former terrorist controlled area, at ca 2500 to $2600 \mathrm{~m}$, where it is protected by some very suspicious and probably battle hardened villagers.

EPonymy: Named in honor and gratitude of Russell F. Stephens Jr., of Sarasota, Florida, who has supported 

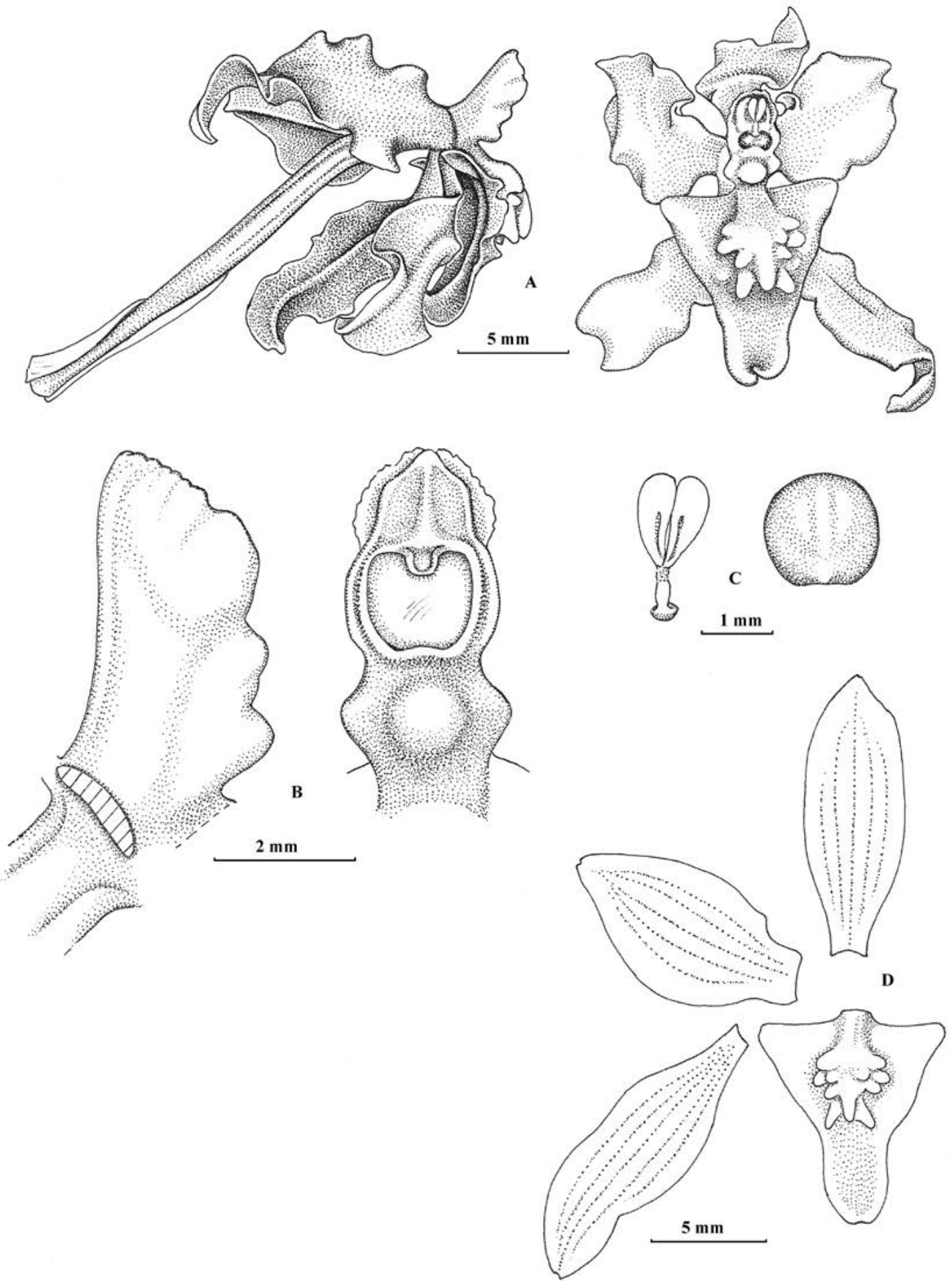

Figure 2. Cyrtochilum russellianum. A. Flower lateral and frontal views. B. Column lateral and ventral views. C. Anther cap and pollinarium. D. Flower dissected. Drawn from holotype by Stig Dalström. 
orchid research by establishing the Friends of Orchid Research Fund (with a particular interest in the orchid flora of Bhutan and Peru), administrated by the Community Foundation of Sarasota County.

Cyrtochilum russellianum is similar to and flowers simultaneously with the sympatric and pale pink-flowered C. carinatum, but differs in the larger flower without a distinct dorsal keel and apical knob on the column. The similarly small flowered $C$. sharoniae also grows sympatrically in the same area and flowers simultaneously with $C$. carinatum and $C$. russellianum, but differs in the dark purple to almost blackish flowers. All three species have lilac columns, a very unusual and interesting circumstance. The vegetative differences, however, are clear between the three species. The pseudobulbs in C. russellianum are normally green, while in $C$. carinatum the base of the pseudobulbs as well as the base of the new growths are dark purplish in the wild. The pseudobulbs in $C$. sharoniae are typically dark green and the leaves have a whitish wax-like coating, similar to some unrelated plants with a pendent habit, such as Euchile citrina (Lex.) Withner, and Masdevallia caesia Roezl.

\section{Cyrtochilum tricornis Dalström \& Ruíz-Pérez, sp. nov.}

TYPE: Peru. Cusco, Quillabamba, Rio Chullapi Reserva, 2000-2200 m, field collected by Luis Valenzuela and his team from the Cusco University, with J. Sönnemark and S. Dalström, 9 Dec. 2002, S. Dalström et al. 2699 (holotype, CUZ). Fig. 3.

Diagnosis: Cyrtochilum tricornis is most similar to C. cimiciferum (Rchb.f.) Dalström, and Cyrtochilum macropus (Linden \& Rchb.f.) Kraenzl., but differs from both by the much smaller floral bracts, the pandurate lip lamina and the three distinct horn-like structures at the apex of the column.

Epiphytic herb. Pseudobulbs caespitose, ovoid, bifoliate, $9.0-11.0 \times 1.5-2.0 \mathrm{~cm}$, surrounded basally by 6 to 8 distichous sheaths, the uppermost foliaceous. Leaves subpetiolate, conduplicate, elliptic to obovate, narrowly acute to acuminate, $29.0-35.0 \times 1.0-2.0$ $\mathrm{cm}$. Inflorescence 1 or 2, axillary from the uppermost sheaths, erect to arching, almost straight to slightly flexuous apically, to $c$ a. $130 \mathrm{~cm}$ long panicle, with many widely spaced, almost straight to slightly flexuous, 3to 6-flowered side-branches. Floral bracts appressed, scale-like, ventrally pubescent, acute, $5.0-10.0 \mathrm{~mm}$ long. Pedicel with ovary 20.0-25.0 mm long. Flowers stellate with deflexed segments; dorsal sepal yellow with brown spots, unguiculate to spathulate, obovate to elliptic laminate, obtuse, weakly undulate, and slightly revolute, ca. $10.0 \times 4.0-5.0 \mathrm{~mm}$; lateral sepals similar in color, spathulate, narrowly and obliquely ovate to elliptic laminate, obtuse, $15.0 \times 6.0 \mathrm{~mm}$; petals similar in color, broadly unguiculate, broadly and slightly obliquely ovate, almost rotundate laminate, obtuse, $c a$. $10.0 \times 6.0 \mathrm{~mm}$; lip similar in color, rigidly attached to the base of the column, basally hastate, trilobate and pandurate with distinct lateral angles, and a rounded, concave, strongly reflexed front lobe, $c a .10 .0 \times 6.0$ $7.0 \mathrm{~mm}$; callus yellow, of a fleshy, tricarinate structure, emerging from the base of the lip and longitudinally extending for about $4.0-5.0 \mathrm{~mm}$, the lateral ridges being shorter and ending in blunt, slightly spreading angles, and the central ridge ending in a slightly swollen, rounded knob; column basally green, then purplish or brownish, apically yellow, erect in a $c a .90^{\circ}$ angle from the base of the lip, stout, straight, with two diffuse spreading, lateral angles, and one central fleshy keel below the stigmatic surface, and three apical horn-like structures, 4-5 mm long; anther cap dark orange to red, with a yellow dorsal stripe, campanulate and minutely papillose; pollinarium of two elongate pyriform, cleft, or folded, pollinia on a minute, less than $0.5 \mathrm{~mm}$ long broadly linear, or rectangular, stipe on a minute, almost triangulate, pulvinate viscidium.

Paratypes: Peru. Pasco, Paucartambo, Ulcumayo, Anexo Yaupi, ca. 2000-2200 m, humid forest at ca 1800-2000 m, field collected by S. Ruíz s.n., and flowered in cultivation at Perúflora, 26 Dec. 2011, S. Dalström 3493 (USM). Same area, $5 \mathrm{~km}$ south of Oxapampa, ca. 1800 m, 30-31 Jan. 1979, C. \& J. Luer 3817, 3837 (SEL). Same area. Oxapampa, Chontabamba, 1200 m, 17 July 1996, J. del Castillo s.n., ex D. E. Bennett 7672; illustration in Icones Orchidacearum Peruviarum, pl. 533 (1998), as "Oncidium saltabundum" (No preserved specimen found).

Distribution: This species is only known from montane areas in the departments of Pasco and Cusco 


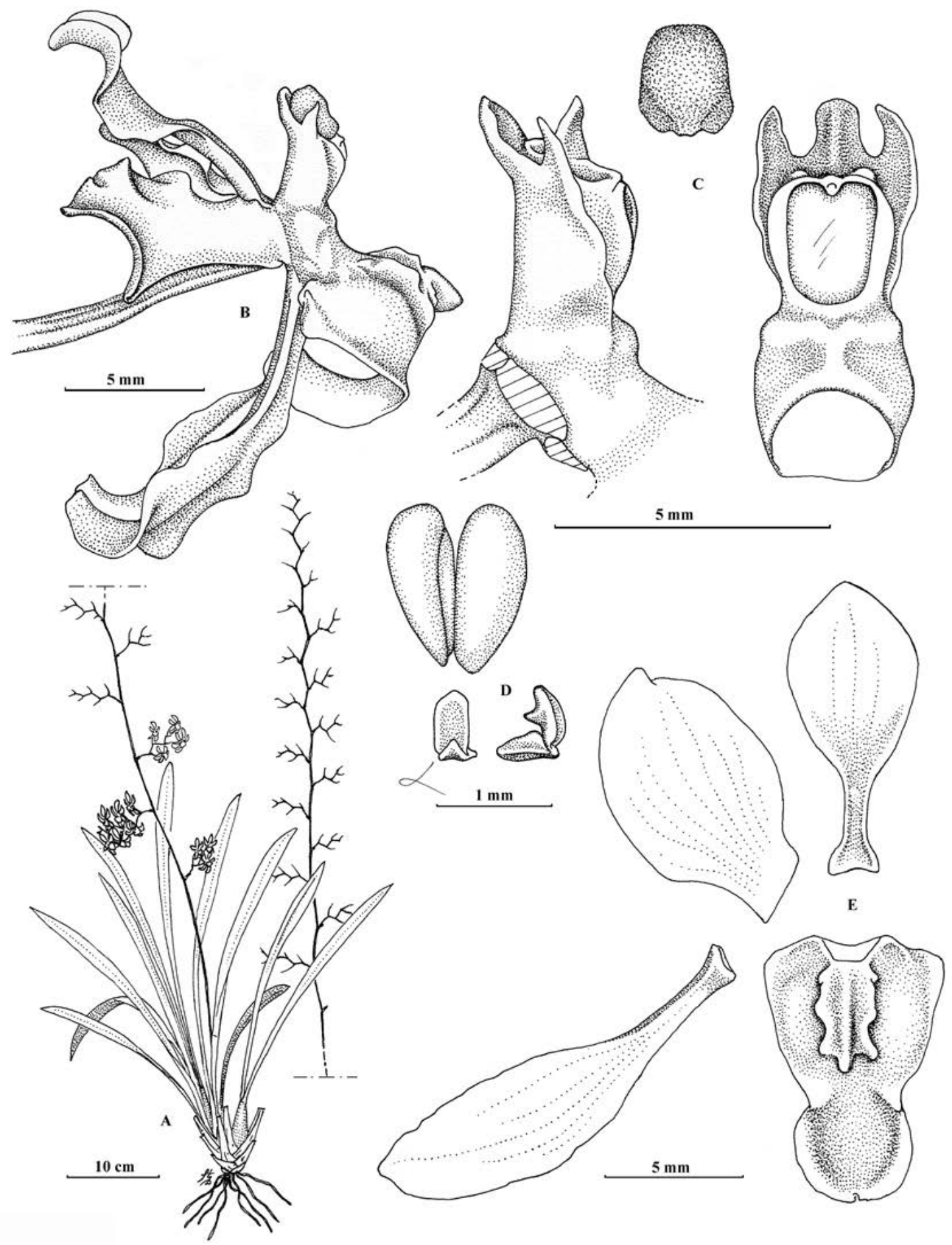

FiguRE 3. Cyrtochilum tricornis. A. Plant habit. B. Flower lateral view. C. Column lateral and ventral views, and anther cap.

D. Pollinarium, with front and lateral views of the stipe. E. Flower dissected. Drawn from holotype by Stig Dalström. 
in central Peru where it occurs as an epiphyte in open and humid forests at 1200-2200 m elevation.

Eтymology: The name refers to the three horn-like structures at the apex of the column.

Cyrtochilum macropus has in previous treatments been considered as a synonym of $C$. cimiciferum (Dalström, 2001), but recent examinations of additional field-collected material and the holotypes show that it should be treated as a distinct species.
ACKNOWLEDGMENT. The authors wish to thank the staff at the Instituto Recursos Naturales (INRENA), and Betty Millán at the Universidad de San Marcos, Museo de Historia Natural, Lima, for aiding in providing the necessary collecting permits. We also wish to thank the staff at the herbaria of CUZ, MO, MOL, SEL and USM, for their assistance in the examinations of preserved plant specimens. We also thank Wesley Higgins for viewing and commenting on the manuscript, Jan Sönnemark of Halmstad, Sweden, for great field company and support, and the Perúflora staff together with the Manuel Arias family in Lima for generous logistic support.

\section{LiTERATURE CITED}

Dalström, S. - 2001. A synopsis of the genus Cyrtochilum (Orchidaceae; Oncidiinae): Taxonomic reevaluation and new combinations. Lindleyana 16(2): 56-80. 